\title{
Corela
}

Cognition, représentation, langage

HS-23 | 2017

The Genesis and Dynamics of Spatial Adpositions

\section{Claude Vandeloise on proximity or the missing piece of a final triptych}

\section{Michel Aurnague and Gilles Col}

\section{(2) OpenEdition}

\section{Journals}

\section{Electronic version}

URL: http://journals.openedition.org/corela/5024

DOI: $10.4000 /$ corela.5024

ISSN: 1638-573X

\section{Publisher}

Cercle linguistique du Centre et de I'Ouest - CerLICO

\section{Electronic reference}

Michel Aurnague and Gilles Col, « Claude Vandeloise on proximity or the missing piece of a final triptych », Corela [Online], HS-23 | 2017, Online since 13 November 2017, connection on 01 May 2019. URL : http://journals.openedition.org/corela/5024 ; DOI : 10.4000/corela.5024

This text was automatically generated on 1 May 2019.

\section{(c) (i) (3) (-)}

Corela - cognition, représentation, langage est mis à disposition selon les termes de la licence Creative Commons Attribution - Pas d'Utilisation Commerciale - Partage dans les Mêmes Conditions 4.0 International. 


\title{
Claude Vandeloise on proximity or the missing piece of a final triptych
}

\author{
Michel Aurnague and Gilles Col
}

\section{A tribute to Claude Vandeloise (1944-2007)}

1 On August 22th 2007, Claude Vandeloise passed away succumbing to a searing cancer. A few months before his death, he had submitted a paper entitled "The expression of proximity in French and in English" to Corela. The evaluation of the paper was still in progress when he died and, as a consequence, it was interrupted. The relations between Vandeloise and Corela were actually not new at that time, since he had showed an enthusiastic support to this online editorial project from the very beginning; his support has even proven to be very important for this young, innovative journal over the years. With distance and hindsight, it seems that the paper submitted to Corela in 2007 is in fact the last article Claude Vandeloise ever writes. The links with other productions (see below) and the insertion of a factual element referring to a search on the web in May 2007 strengthen this assumption. It then occurred to us that this text should be brought to the attention of the linguistic research community. In order to make it as accessible as possible and given the close ties of Vandeloise with Corela, we thought that a publication in this open access journal was all the more appropriate.

2 Rediscovering this text about proximity ten years later made us remind the richness of $C$. Vandeloise's analyses and the many avenues they are likely to open to the researchers, despite some possible punctual discrepancies. We also noticed the close relations between this contribution on proximity and two other papers written between 2005 and 2007. The first paper is a deep reflection on the genesis of spatial terms or adpositions in language published in (Evans and Chilton 2010). The second one, posthumous as well, aims at

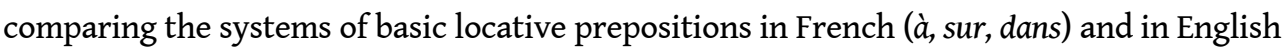
(at, on, in; to, onto, into) and the way control (containment, support...) and localization interact in these two languages. This latter work appeared in the series of internal reports of CLLE-ERSS laboratory in Toulouse (Vandeloise 2008) and thus gave rise to a 
quite limited distribution. Apart from the parallel analysis of French and English data carried out in two contributions - a rather unusual practice in Vandeloise's publications - , the three of them are clearly guided by several recurrent concerns : lexical formation and the genesis of spatial adpositions ; the opposition and split between the expression of control and that of localization; the reference to proximity and its connections to other spatial relations... Because of these many links, we thought that the unpublished work on proximity by $\mathrm{C}$. Vandeloise deserved to be published together with the two papers previously mentioned, one of which is also rather unknown. The contents of the different contributions of this special issue and their relationships will be further commented on in the following section. Before that, let us indicate that we decided to present these contributions in the order they have been written by the author (according to several clues), starting with the reflections on the genesis of spatial terms, following with the comparative analysis of basic prepositions of French and English, and ending with the study about the expression of proximity.

\section{Control vs. localization as a main thread}

3 Therefore, the first paper of this special issue of Corela reproduces the penetrating reflections on the "genesis of spatial terms" or adpositions in language posthumously published in (Vandeloise 2010). The question of lexical formation, very present throughout the text, is first introduced via the well-known research trend on color terms (Berlin and Kay 1969). As stated by MacLaury (1991) in his work on Tzeltal and Tzotzil, the color terms of these two Mayan languages seem to have emerged via a process of internal lexical formation by division. In such a process, a term used for referring to a set of facts or situations starts to compete with another term coined by the more creative speakers in order to delimit a prominent subset of facts within the original set. After a period of "cohabitation" (the general and the more precise terms can equally be used for denoting the subset of situations), the new word becomes mandatory for the subset of situations, while the general term gets confined to the remaining facts -corresponding to the complementary part of the original set. But all the color terms in Berlin and Kay's famous "implicational scale" cannot be created in this way according to Vandeloise -in particular those situated at the two ends of the scale: white and black, brown- and the existence of another kind of process called "external lexical formation" has to be postulated: "It occurs when the members of a society share a common interest in an aspect of their environment or their social life; when they are able to recognize this aspect in a sufficiently similar way ; and when they associate a term to this aspect of their lives" (quoted from the first paper). Then, Vandeloise turns to the implicational scale proposed by Levinson and Meira (2003) for the emergence of (static) spatial topological relations in language. This scale was elaborated through an elicitation task carried out in a sample of genetically unrelated languages, from which it appears that locative adpositions are divided into compact subsets corresponding to specific statistical attractors or foci. Levinson and Meira's method is similar to Berlin and Kay's and the scale set out seems to be underlain by a process of internal lexical formation by division. Vandeloise levels several important criticisms to Levinson and Meira's proposal: projective relations and adpositions (e.g., in front of, behind) are left aside from the study ; the meaning of the relations under examination is exclusively expressed in terms of topological and, more generally, geometrical notions, without accounting for their 
possible "functional" content in terms, for instance, of force dynamics; the majority of concepts/meanings in the hierarchy are labelled by names of English prepositions (e.g., AT, IN, INSIDE, NEAR, ON, ON TOP, OVER). More punctual objections are also raised concerning the way some spatial relations have been brought together in the implicational scale or hierarchy (e.g., ON with OVER, ON TOP OF and ATTACHMENT; "two-dimensional" and "three-dimensional" IN) ignoring, among other things, the differences between the general or prototypical value of some adpositions and the possible developments from this central meaning. Relying on previous sketches (Vandeloise 2003c, 2005), Vandeloise proposes an alternative hierarchy of concepts which is governed by a fundamental contrast between the adpositions that imply an exchange of forces between the target (located entity) and the landmark (locating or reference entity) -called "dynamic" spatial adpositions- and those that rather involve coincidence or proximity between these two elements, the position of the landmark within an encompassing frame of reference being usually well known. This opposition is very pervasive in Vandeloise's work and goes back to his first investigations where configurational prepositions were opposed to localizing or positional ones (see, in particular, Vandeloise 1987a, 1988). The root of the new hierarchy of concepts corresponds to a general locative adposition denoting "relation in space" (like ta in Tzeltal) which splits up into two subsystems, one of which is thus devoted to the expression of "control" (forces, dynamic adpositions) and the other to true localization. General control (e.g., en in Spanish) can give rise to successive refinements : containment vs. support, different kinds of containment (e.g, tight fit, loose fit), different kinds of support (e.g., direct support, indirect support). The creation of new elements in this part of the hierarchy seems to rely on external lexical formation (see previously) as a spatial adposition can be introduced by a language at any level of the scale without necessarily having to go from general concepts to specific ones. On the other hand, the subpart of the hierarchy that involves true localization grows through internal lexical formation by division, starting with a general marker (e.g., locating uses of $\grave{a}$ in French) that later opens the way to the creation of projective adpositions referring to "vertical separation" (e.g., au-dessus/en dessous in French) and then to "horizontal separation" (e.g., devant/ derrière, à gauche/à droite in French). While discussing and comparing the two implicational scales, Vandeloise touches several questions that will be addressed in depth in the following contributions of the special issue: the relations between static and kinetic uses of locative adpositions; the interactions between control (in particular containment) and localization when landmarks are geographical locations/places; the expression of proximity and the way it should be integrated in the hierarchy of concepts ; the status of infrativity (e.g., sous, under) with respect to control and localization and its interactions with the notion of support (e.g., sur, on).

4 The analysis follows by focusing on the modes of development (of words) entailed by the two kinds of lexical formation processes previously highlighted, taking a three-level hierarchy of words and concepts as a template. While internal lexical formation by division relies on a unique mode of development going from the more general category to the more specific one (through the intermediate level), external lexical formation can directly operate at any level of the hierarchy and is likely to involve two more modes of development: one goes from the more specific category (first accessed) to the more general one (internal lexical formation by union) whereas the other provides an access to the intermediate level of the hierarchy together with parallel extensions towards the 
more general and the more specific levels. Vandeloise relates the latter mode of formation with the importance attached to basic or generic categories when building taxonomies (Rosch 1973, Rosch and Mervis 1975). This comprehensive analysis is supplemented by a final reflection on the acquisition of spatial adpositions where Vandeloise draws a main distinction between deterministic and non-deterministic approaches of the relations language vs. thought -do child have pre-linguistic concepts ? - and evaluates which modes of development among those previously commented on are likely to operate according to several views (universal, relativist or even individualistic).

5 The second work of this special issue ("Three basic prepositions in French and in English : a comparison), first edited as an internal report by the laboratory CLLE-ERSS (Vandeloise 2008), elaborates upon two questions evoked when discussing the genesis of spatial adpositions in the previous paper. As a matter of fact, the connections between static and kinetic adpositions were the subject of a preliminary remark about the evolution of the preposition $œ t$ in Old English and its uses related to the expression of the source (later expressed by from) and goal (later expressed by to) of motion. ${ }^{2}$ The interactions between control (in particular containment) and localization were also commented on in relation with the adpositions selected by country and city names. These two issues are thus deepened in this second work by comparing the systems of basic locative relations in French (à, sur, dans) and in English (at, on, in ; to, onto, into).

$6 \quad$ While static space is central in Vandeloise's work, kinetic relations between entities were studied sporadically, for instance through the analysis of the preposition $\grave{a}$ (Vandeloise 1987a) or the verb aller 'to go (to)' (Vandeloise 2007) - see also Vandeloise 2001. The present paper takes as its starting point the "principle of anticipation" introduced in (Vandeloise 1987a) in order to state that the prepositions of French denoting a static locative relation can, in association with a kinetic verb like aller, equally indicate the prospective position of a moving target with respect to a landmark. Successive formulations are proposed in order to ensure that this principle only applies to verbs that really involve a prospective localization (aller vs. arriver 'to arrive', marcher 'to walk') and that it is also sensitive to the "final" or "initial" nature of the "reference place" (Laur 1993) underlying the verbal meaning (aller vs. partir 'to leave'). In its completed version, the principle of anticipation is supposed to provide a global account of the reuse of static spatial prepositions in kinetic contexts in French and this principle of course applies to the three basic prepositions $\grave{a}$, sur and dans. Indeed, the first section of this work is the occasion for the author to recall that à gives rise to two different uses (Vandeloise 1987a), one of which is based on the true localization of the target via a landmark whose position has to be specified or well known, while the other indicates that the target is involved in a social "routine" suggested by the landmark.

7 Then, Vandeloise turns to English data with the preposition to whose meaning, he claims, encodes itself the prospective position of a moving target (without this prospective content depending on the semantics of the verb like in French). The presence of adpositional elements expressing a "path" such as to, into and onto is not surprising in a language which is "satellite-framed" according to Talmy's $(1985,2000)$ famous typology, as opposed to French which encodes the path component of a motion in the verb ("verbframed language"). However, the principle of anticipation is also useful in English for those static prepositions lacking a prospective equivalent in the kinetic domain (e.g., under, in front of) and Vandeloise shapes a specific version of the principle that integrates this restriction. 
8 The relationships between to, into and onto is another topic of this paper. Diachronically to was the first to appear and, for a long time, it competed with the preposition œet whose former value in old English included the expression of the goal of a motion event (probably via the principle of anticipation). According to Vandeloise, into and onto emerged as elaborations of to rather than as elaborations of in and on, and their semantic content introduces the prospective container or support of the target, just as to denotes the prospective position of the target. With regard to morphology, it is suggested that the formation of into and onto from two independent morphemes (in and to, on and to) may have followed the pattern of noun compounds in English with the element on the left (in or on) modifying that on the right (to) which, therefore, operates as a head. This pattern is totally consonant with the semantic functioning (elaboration of to by in and on) and, according to Vandeloise, it is also likely to overcome the difficulties which the proposals set out within the theoretical framework of distributed morphology are faced with (e.g., Thomas 2005).

9 The last part of this contribution comes back to the split put forward in the hierarchy of concepts proposed in the first paper in order to explain the genesis of spatial terms in language. It is recalled that, because they involve control and forces, dynamic adpositions relate material targets to landmarks. On the other hand, static adpositions that denote the true localization of a target usually resort to immaterial landmarks, that is to say "spatial entities" in Vandeloise's terminology. However, these two options are not so clear cut and some overlapping can occur for those immaterial or spatial entities associated with some kind of boundary. That is the case for geographical locations/places which, although made up of a portion of space or region, are often delimited by a frontier. This kind of landmarks are likely to match several of the features or traits integrated in the family resemblance defining the container/content relation. Vandeloise also brings to the fore the notion of "zone of influence" which is sometimes responsible for relating spatial landmarks to the more prototypical situations of control (this notion was already pointed out in Vandeloise 2001). The author shows in a very convincing way that while French and English adpositional systems mainly coincide for clear cases of control (e.g., dans la boite, in the box) and localization (e.g., au carrefour, at the crossroads), they may also converge when a zone of influence is involved (e.g., dans la forêt, in the forest) but diverge in presence of country or city names (e.g., à Paris, in Paris). Proper names of geographical locations/places are indeed very illustrative of the possible overlapping between localization and control : while they are supposed to uniquely identify the position of the landmark in a given context (allowing the speaker to locate the target through coincidence, contiguity or proximity: $\grave{a}, a t)$, they also refer to entities that are often equipped with boundaries and open the way to a conceptualization based on containment (dans, in). The processing of these intermediary situations will be thus determined by the choices made in each language.

10 As already said, the third text presented here ("The expression of proximity in French and in English") was never published. It clearly echoes the first paper on the genesis of spatial adpositions and, at the same time, offers a parallel analysis of French and English data, as in the previous contribution. The central question emphasized in this text is: which place or position has to be assigned to proximity expressions in the hierarchy of concepts governing the emergence of locative markers (a point already discussed in the first paper)? Before that, Vandeloise singles out the meaning constraints that underlie 
proximity adpositions in French and in English as well as the different "perspectives" from which proximity is assessed in these two languages.

11 According to Vandeloise, the semantics of proximity expressions in French and in English is conditioned by the ease or difficulty of access to the target which itself depends on the size and speed of (a) the target, (b) the landmark, (c) the speaker, and (d) the addressee. Ease or difficulty is also determined by (e) the facility of the access (e.g., properties of the path joining the landmark to the target) and (f) its type (e.g., physical access, perception). Although accessibility is not reducible to distance, this element plays an obvious role in its assessment and, in "objective" contexts -related to geography or physics for instance-, it sometimes becomes the most important or even the unique factor conditioning the resort to proximity expressions. Thus, together with the main "usage rule" referring to the ease or difficulty of access ("impetus", see section 3), Vandeloise introduces a second rule which is an extension of the former intended to account for cases based on the sole distance criterion (with distance evaluated through a scale depending on the sizes/dimensions of the target and the landmark). This theoretical design is slightly different from the analysis originally proposed in (Vandeloise 1986, 1991) where distance was given a more central paper.

12 The author remarks that in a way similar to projective prepositions such as behind or derrière involving a third element in their functioning - distinct from both the target and the landmark-, an additional entity is often implied by the notion of access in the expression of proximity. In terms of perspective, to in the complex prepositions near to or close to denotes the prospective final position of the target in a motion, whereas from in far from introduces its origin. English utterances integrating these two kinds of prepositions are likely to generate divergent perspectives contrary to French where près de and loin de rely on one and the same perspectivation process. Moreover, near to and close to are better fitted for spatial situations with a moving target as well as for temporal or notional descriptions than for static spatial situations. The reverse occurs with près de, loin de and far from as the underlying perspective (initial position of the target accessed from the landmark) seems to be more compatible with a static configuration.

13 The paper concludes with a reflection on the way adpositions of proximity may be integrated in the hierarchy proposed for explaining the emergence of static spatial terms in language. For the sake of the demonstration, Vandeloise resorts to a simplified version of the implicational scale or hierarchy of relationships set out in the first of the three papers of this special issue. In particular, the split between control and localization is graphically less obvious (than in the first version) because all the concepts/relations are distributed along a unique branch which gives rise to successive creations through internal lexical formation (by division). The hierarchy is mainly focused on French whose locative adpositions are supposed to materialize the meaning components commented on in the text. The first elements that pull away from the root of the hierarchy (most general locative marker) are the dynamic adpositions entailing an exchange of forces like dans (containment) and sur (support). Next comes the preposition sous that does not systematically denote situations of control (exchange of forces) but is closely related to the notion of "access to perception". According to Vandeloise, sous is less dynamic than dans and sur but more functional than the adpositions relying on the notion of localization. The latter adpositions (of localization) are the next to appear in the hierarchy, first with the locating use of $\grave{a}$ and then with different projective markers (the 
use of à based on social routines emerges as an independent extension of its locating meaning). ${ }^{3}$

In the lower part of the chart, vertical spatial relationships (projective prepositions audessus de/en dessous de) detach themselves from the hierarchy before horizontal markers ( devant/derrière, à gauche/à droite), as the latter but not the former are compatible with the expression of proximity: the description The lamp is near the table is not easily substitutable for The lamp is on the table whereas The tree is near the house can perfectly be uttered together with The tree is in front/on the left of the house. A last question remains to be addressed in relation with adpositions of horizontal separation or proximity: do proximity expressions (e.g., près de/loin de, near (to)/far from) appear before projective adpositions (e.g., devant/derrière, à gauche/à droite; in front/behind, on the left/on the right) or the other way around? Vandeloise keeps the two options opened and adds a third scenario in which proximity terms would have developed independently of the present hierarchy of spatial relationships. Several elements support the idea that proximity adpositions may have emerged in a quite independent and late manner, specifically their morphologically complex form and the various status of the elements they are made up of (e.g., adjectives, adverbs, verbs). In spite of proximity adpositions conveying a quite general notion possibly involved in most spatial configurations, Vandeloise claims that it is not a surprise that dynamic markers denoting containment or support emerge first in the diachronic development of languages (phylogeny): "The priority of complex functional notions comes as a surprise only if one expects languages to proceed from the descriptively simple notions to the more complex ones. In fact, languages are devised to help our adjustement to the world and to society. Functional relationships fit this purpose better than general abstract notions".

\section{Function in space : the many facets of a work}

15 As we can see, the three contributions brought together in this special issue are related in several ways and offer a coherent and profound immersion in C. Vandeloise's work. They are guided by important concerns that seem to structure the author's last reflections and productions such as the emergence of spatial terms in language and the comparison of basic spatial prepositions in French and in English. Of course, these very rich and impressive analyses are not free from weaknesses and a series of criticisms could surely be made in relation with specific points. Let us mention two or three of them by way of example. In relation with the second paper, for instance, one could expect to be provided with a more detailed description of motion verbs internal structure when claiming the application of the principle of anticipation to some predicates (e.g., aller and to go (to)) but not to other (e.g., arriver and to arrive). Also, the fact that the French preposition au can sometimes stand for en le (rather than for à le; see Molinier 1990) and the semantic connections between en and dans are likely to partly blur the differences highlighted between French and English with respect to the prepositions associated with (masculine) country names - however, the difference remains for most city names. Another criticism could be addressed to the implicational scale or hierarchy of spatial concepts proposed in the first paper and taken up in a simplified version in the last work on proximity. As indicated, this hierarchy is crucially based on the opposition between exchange of forces (dynamic adpositions) and mere localization. It could be argued that, by focusing on forces, Vandeloise leaves aside many other functional factors (e.g., access 
to perception, orientation, social routines) that would have allowed him to widen its initial opposition. In particular, a fundamental split appears between the (functional) locative adpositions which need both the landmark and the target (and sometimes a third element) to be taken into account -in a true relational fashion- in order to "compute" the spatial configuration described, and those whose semantics can be reduced to the mere geometrical inclusion of the target in a region associated with the landmark. ${ }^{4}$ As pointed out in (Aurnague 2011) and (Aurnague and Vieu 2015), this important contrast leads to refine the famous opposition between "what" and "where" systems in language and cognition (Landau and Jackendoff 1993, Ungerleider and Mishkin 1982) and to divide the original "where" system into two components: a genuine "where" component (geometrical way of locating) and a "how" component (functional way of locating). A similar reformulation of the debate on "what" and "where" has been recently defended by Landau (2017) who, however, resorts to a division of labor (force-dynamic vs. geometry) that seems rather close to Vandeloise's original one.

16 Beyond the possible criticisms, the latter remarks remind us that Vandeloise was probably the first linguist to highlight the limits of a purely geometrical approach of locative prepositions and to propose a theoretical framework really accounting for the "functional" aspects of spatial interactions between entities (Langacker 2010). ${ }^{5}$ Many hypotheses early formulated by Vandeloise have been confirmed by psycholinguistic experiments (see, for instance, the studies gathered in (Carlson and van der Zee 2005)) and his outstanding contribution to spatial semantics in language and cognition has been regularly noted by cognitive psychologists (e.g., Denis 2016).

Indeed, from the very start of his investigations on the expression of space in French, Vandeloise $(1984,1986,1991)$ developed its own framework of analysis -within the trend of cognitive linguistics - and went on using and enhancing it until the last written work gathered in this special issue (Aurnague 2008). He defined five groups of functional universal features that, according to him, should be taken into account when examining the semantics of spatial prepositions/adpositions : anthropomorphic principles/form of the human body, naive physics, access to perception, potential encounter, and general and lateral orientations. He also claimed that the meaning of each locative adposition was associated with a central concept called "impetus", underlain by a set of features or traits that make up a family resemblance network (Wittgenstein 1953). This family resemblance shows itself through the formation of usage rules (one or more for an adposition), based on the impetus or on a subset of its constituent features -and accompanied by selection restrictions, if needed. Vandeloise did not only brought to the fore the notion of containment or container/content (preposition dans) and the various properties underlying this concept (control, no limit transgressing, relative motion, envelopment, protection, hiding; see the second paper in this special issue). He dealt with many more prepositions for which he tried to determine a relevant impetus intended to account for their distribution (as well as a series of features or properties for each impetus; see above) $:^{6} \grave{a}$ [specified position/location, social routines], à gauche/à droite [lateral orientation], au-dessus/en dessous [position with respect to the vertical axis], avant/après [potential encounter], contre [atypical encounter], devant/derrière [general orientation, access to perception], hors de [outward motion], sur/sous [support or bearer/ burden]...7 The posthumous work on the expression of proximity in French and in English is a good example of how Vandeloise managed to retrieve the appropriate impetus (here 
access or accessibility) from the analysis of adpositions and defined one or more usage rules in relation with the set of features underlying this impetus.

Together with the early definition of a precise theoretical framework, it is striking to note how much $\mathrm{C}$. Vandeloise was worried about confronting his analyses and assumptions to other data, approaches and domains. Throughout his academic career, he showed a great interest for the results and debates arising in three specific areas: acquisition of language, cross-linguistic studies (and linguistic relativity), diachrony (and the phylogeny of languages). Although Vandeloise's concern with acquisition appeared very early (Vandeloise 1987b), then this question was often associated with that of language comparison and linguistic relativity (e.g., Vandeloise 2003a, 2003b, 2003c, 2005). As regards diachrony, except incidental references, a comprehensive reflection on this linguistic dimension was proposed later, with the author's work on the emergence of spatial terms (again in connection with cross-linguistic concerns) and, in the first place, the contribution on this topic reproduced here.

On the whole, the three papers gathered in this spatial issue give a good idea of C. Vandeloise's theoretical approach, questionings and varied areas of interest in relation to the semantics of spatial markers in language. While maintaining a clear consistency with most of his previous work, they also emphasize the specific points and debates in which the author was involved shortly before his death in August 2007. May the publication of these last studies contribute to introduce (or reintroduce) research fellows and students into a rich and prolific thinking, beyond ephemeral trends and a publication race that often induces us to prioritize alleged novelties.

\section{BIBLIOGRAPHY}

Aurnague, M. (2008). Claude Vandeloise : obra baten mugarriak [Claude Vandeloise : the milestones of his work]. Gogoa, 8 (1) : 9-24.

Aurnague, M. (2010). Claude Vandeloise : bibliographie des travaux / bibliography of his works. Corela, HS-7, http://corela.revues.org/1755

Aurnague, M. (2011). Fonction(s) vs. régions dans le sémantisme des relations spatiales : une distinction fondamentale. Symposium Un parcours de neuropsycholinguistique en hommage au professeur Jean-Luc Nespoulous. 28-29 January 2011, Université de Toulouse-Le Mirail, https:// hal.archives-ouvertes.fr/hal-00940526v1

Aurnague, M. \& Vieu, L. (2015). Function versus regions in spatial language : a fundamental distinction. In C. Astésano and M. Jucla (Eds.), Neuropsycholinguistic perspectives on language cognition. Essays in honour of Jean-Luc Nespoulous. London/New York : Psychology Press, 31-45.

Berlin, B. \& Key, P. (1969). Basic color terms : their universality and evolution. Berkeley \& Los Angeles : The University of California Press.

Carlson L. \& van der Zee, E. (Eds.) (2005). Functional features in language and space : insights from perception, categorization, and development. Oxford : Oxford University Press. 
Denis, M. (2016). Petit traité de l'espace : un parcours pluridisciplinaire. Bruxelles : Mardaga. [English edition (to appear). Space and spatial cognition : a multidisciplinary perspective. Abingdon/New York : Routledge.]

Evans, V. \& Chilton, P. (2010). Language, cognition and space : the state of the art and new directions. London : Equinox.

Herskovits, A. (1982). Space and the prepositions in English : regularities and irregularities in a complex domain. PhD dissertation, Stanford University.

Herskovits, A. (1986). Language and spatial cognition : an interdisciplinary study of the prepositions in English. Cambridge : Cambridge University Press.

Landau, B. (2017). Update on "what" and "where" in spatial language : a new division of labor for spatial terms. Cognitive Science, 41(S2) : 321-350.

Landau, B. \& Jackendoff, R. (1993). "What" and "where" in spatial language and spatial cognition. Behavioral and Brain Sciences, 16 : 217-238.

Langacker, R.W. (2010). Reflections on the functional characterization of spatial prepositions. Corela, HS-7, https://corela.revues.org/999

Laur, D. (1993). La relation entre le verbe et la préposition dans la sémantique du déplacement. Langages, $110: 47-67$.

Leech G.N. (1969). Towards a semantic description of English. London : Longman.

Levinson, S. \& Meira, S. (2003). Natural concepts in the spatial topological domain -adpositional meanings. Language, 79(3), 485-516.

MacLaury, R. (1991). Social and cognitive motivations of change : measuring variability in color semantics. Language, 67(1): 34-62.

Molinier, C. (1990). Les quatres saisons - A propos d'une classe d'adverbes temporels. Langue Française, $86: 46-50$.

Rosch, E.H. (1973). Natural categories. Cognitive Psychology, 4(3) : 328-350.

Rosch, E.H. \& Mervis, C. (1975). Family resemblances : studies in the internal structure of categories. Cognitive Psychology, 7(4) : 573-605.

Talmy L. (1983). How language structures space. In H.L. Pick \& L.P. Acredolo (Eds.), Spatial orientation : theory, research and application. New York : Plenum Publishing Corporation, 225-282.

Talmy, L. (1985). Lexicalization patterns : semantic structure in lexical forms. In T. Shopen (Ed.), Language typology and syntactic description (Vol. 3) : grammatical categories and the lexicon. Cambridge : Cambridge University Press, 57-143.

Talmy, L. (2000). Towards a cognitive semantics. Cambridge, MA : The MIT Press.

Thomas, E. (2005). On 'syntactic' versus 'semantic' telicity : evidence from in and on. Belgian Journal of Linguistics, $18: 145-166$.

Ungerleider, L.G. \& Mishkin, M. (1982). Two cortical systems. In D.J. Ingle, M.A. Goodale \& R.J.W. Mansfeld (Eds.), Analysis of visual behavior. Cambridge, MA : MIT Press, 549-586.

Vandeloise, C. (1984). Description of space in French. PhD dissertation, University of California, San Diego. Duisburg : LAUTD.

Vandeloise, C. (1986). L'espace en français : sémantique des prépositions spatiales. Paris : Editions du Seuil. 
Vandeloise, C. (1987a). La préposition à et le principe d'anticipation. Langue Française, 76 : 77-111.

Vandeloise, C. (1987b). Complex primitives in language acquisition. Belgian Journal of Linguistics, 2 : 11-36.

Vandeloise, C. (1988). Les usages spatiaux statiques de la préposition à. Cahiers de Lexicologie, 53 : 119-148.

Vandeloise, C. (1991). Spatial prepositions : a case study in French. Chicago, IL : The University of Chicago Press.

Vandeloise, C. (2001). Aristote et le lexique de l'espace : rencontres entre la physique grecque et la linguistique cognitive. Stanford, CA : CSLI.

Vandeloise, C. (2003a). Langues et cognition. Paris : Hermes.

Vandeloise, C. (2003b). Acquisition des termes spatiaux et relativisme linguistique. In C.

Vandeloise (Ed.), Langues et cognition. Paris : Hermes, 279-301.

Vandeloise, C. (2003c). Containment, support and linguistic relativity. In H. Cuyckens, R. Dirven \& J. Taylor (Eds.), Cognitive approaches to lexical linguistics. Berlin : Mouton de Gruyter, 393-425.

Vandeloise, C. (2005). Force and function in the acquisition of the preposition in. In L. Carlson \& E. van der Zee (Eds.), Functional features in language and space : insights from perception, categorization, and development. Oxford : Oxford University Press, 219-232.

Vandeloise, C. (2007). Le verbe aller : l'affranchissement du contexte d'énonciation immédiat. Journal of French Language Studies, 17(3) : 343-359.

Vandeloise, C. (2008). Three basic prepositions in French and in English : a comparison. Carnets de Grammaire, 19. Toulouse : CLLE-ERSS report.

Vandeloise, C. (2010). Genesis of spatial terms. In V. Evans \& P. Chilton (Eds.), Language, cognition and space : the state of the art and new directions. London : Equinox, 171-192.

Wittgenstein, L. (1953). Philosophical investigations. New York : MacMillan.

\section{NOTES}

1. The publication of this special issue of Corela has been made possible thanks to the financial support provided by CLLE-ERSS (Université de Toulouse, CNRS, UT2J) and CerLiCO (Cercle Linguistique du Centre et de l'Ouest). We also like to thank Vyvyan Evans, co-editor of the book Language, cognition and space : the state of the art and new directions (London : Equinox, 2010) for his help in the different steps for republishing the first of the three papers. Last but not least, we are grateful to Dejan Stosic who pointed out to us several mistakes in one of the texts of the special issue.

2. As it could be noted, Vandeloise refers to non-static localization with the term "kinetic" while the adjective "dynamic" is restricted to static adpositions implying an exchange of forces between the target and the landmark.

3. Recall that in the full version of the hierarchy (first contribution of this special issue; see above), adpositions of localization are situated in an independent branch and are supposed to convey coincidence or proximity with respect to the landmark. Moreover, localization prepositions like à often select spatial or immaterial entities as landmarks and, specifically, geographical locations or places.

4. Moreover, a revised "cartography" of locative adpositions does not only have to integrate projective relationships (as claimed by Vandeloise when commenting on Levinson and Meira's 
(2003) implicational scale) but also the complex terms based on relational spatial nouns or "Internal Localization Nouns" which, in many languages of the world, form the most important class of markers involving a regional localization process.

5. Untill the 1980s, almost all of the sporadic research on spatial markers was formulated in terms of geometrical notions and tools (see, e.g., Leech 1969). Even at the time of Vandeloise's first publications, important proposals like Talmy's (1983) and Herskovits's $(1982,1986)$ ones were still predominantly geometrical (Aurnague and Vieu 2015). For instance, Talmy's account of spatial prepositions' semantics relies on the assignation of (geometrical) "abstract schemas" to entities and configurations via mechanisms like "idealization" or "abstraction" (Herskovits's "core/ideal meaning" is also geometrical in essence). Force dynamics, a central parameter of functional interactions between entities of the world, has been studied in depth by Talmy but, surprisingly, it was mainly applied to the analysis of causative and/or aspectual constructions and markers, not to the semantics of locative adpositions.

6. The prepositions à and devant/derrière come with two concepts. The first one is the true impetus whereas the second one aims at accounting for meaning extensions diachronically and/ or pragmatically derived from the central concept.

7. Vandeloise also identified several pragmatic rules applying to the spatial domain and included the corresponding principles in his theoretical framework: proximity principle, fixation principle, transfer principle... Some of these principles allow him, for instance, to relate the derived uses of an adposition to its normal uses.

\section{ABSTRACTS}

Once recalled the close ties Claude Vandeloise had with Corela, this introduction focuses on the unpublished work the author dedicated to the expression of proximity in French and in English. This work is put in relation with two other contributions, one on the genesis of spatial adpositions and the other one on the relations between control and localization in the semantics of basic prepositions in French and in English. These three papers, probably written between 2005 and 2007, build up an outstanding collection bringing to the fore the depth of claude Vandeloise's analysis. They also show how the theoretical framework he set up to account for the semantics of spatial markers is continuously questioned in the light of the facts provided by the diachronic, cross-linguistic or acquisitional studies. Once collected, these three papers represent Claude Vandeloise's scientific testament and the completion of his work.

Après avoir rappelé les liens qu'entretenait Claude Vandeloise avec la revue Corela, cette introduction se focalise sur le travail inédit de l'auteur consacré à l'expression de la proximité en français et en anglais. Ce travail est mis en relation avec deux autres contributions sur la genèse des adpositions spatiales d'une part et sur les liens entre contrôle et localisation dans le sémantisme des prépositions de base du français et de l'anglais d'autre part. Ces trois articles, sans doute écrits entre 2005 et 2007, forment un ensemble remarquable qui met en évidence la profondeur des analyses de Claude Vandeloise et montre comment le cadre théorique mis sur pied pour rendre compte de la sémantique des marqueurs spatiaux est sans cesse questionné à la lumière des faits fournis par les études diachroniques, inter-linguistiques ou sur l'acquisition. Les trois textes réunis forment une sorte d'aboutissement et de testament scientifiques de Claude Vandeloise. 
INDEX

Mots-clés: Claude Vandeloise, derniers écrits, genèse des adpositions spatiales, contrôle, localisation, proximité, contenu fonctionnel des marqueurs spatiaux

Keywords: Claude Vandeloise, last written works, genesis of spatial adpositions, control, localization, proximity, functional content of spatial markers

\section{AUTHORS}

MICHEL AURNAGUE

CLLE-ERSS, Université de Toulouse, CNRS, UT2J, France

\section{GILLES COL}

Université de Poitiers, FORELL, France 